\title{
The Role of Counselors in Helping to Improve the Self-Image of Female Prisoners: Challenges for Guidance and Counseling Services
}

\author{
Indah Sukmawati \\ Department of Guidance and Counseling \\ Universitas Negeri Padang, Indonesia \\ i.watsan@gmail.com \\ Bunga Adelya \\ Department of Guidance and Counseling \\ Universitas Negeri Padang, Indonesia \\ bungaadelya13@gmail.com
}

\author{
Afdal \\ Department of Guidance and Counseling \\ Universitas Negeri Padang, Indonesia \\ Afdal@konselor.org \\ Wiwin Andriani \\ Department of Guidance and Counseling \\ Universitas Negeri Padang, Indonesia \\ wiwinandriani293@gmail.com
}

\begin{abstract}
Female prisoners are likely to experience psychological problems, especially related to self-image such as loss of identity and personality, loss of self-control, difficulty adjusting, having low self-esteem, difficult to accept the present situation, reduced self-confidence and a high sense of despair. Self image will have an impact on the formation of personality and wrong development of female prisoners. Therefore, intervention and counseling service interventions are needed to improve the self image experienced by female prisoners. This study aims to examine the self-image of female prisoners, and the role of counselors in helping to improve the self-image. The research method used was a literature study of the dimensions of self-image in female prisoners associated with the guidance and counseling service interventions. Discussion and implications are discussed further.
\end{abstract}

Keywords: self image, female prisoner, counselor

\section{INTRODUCTION}

Criminal acts are all kinds of actions and actions that violate the law, social norms, and religion so as to make people uneasy or against it [1]. Criminal acts are not only committed by men, but women also have the potential to commit crimes [2].

Women who commit crimes may be sentenced to prison and may change their status to prisoners who are detained within a predetermined period of time under certain laws. Life in prison is always monotonous, rude and restricted. Prisoners can lose their jobs, freedom and physical security as well as sincere relationships with others. The sentences not only affect prisoners in prison, but will also affect prisoners after being released from prison.

The length of sentence that must be served will affect the physical and psychological condition of a prisoner [3]. Prolonged punishment will cause prisoners to feel that they are not part of the community and difficult to adapt to being accepted by the community, so that their confidence is reduced, and they have low selfesteem [4]. This will cause inner pressure so that it has autistic tendencies and attempts to escape from traumatic reality[2]. One of the problems experienced by prisoners is the loss of self-control [5]. Based on the results of research conducted by [6] to 20 inmates at the Bukittinggi Class II A penitentiary, 11 inmates claimed to feel bad, 8 inmates felt sorry and 10 inmates felt guilty about themselves.

Feelings like that will cause the formation of a negative self image [7] Self-image is a picture of an individual's self who has been formed from childhood [8]. Every individual is required to be able to build a positive self-image and not only concerns about body shape and physical appearance but also concerns about feelings, attitudes, behavior, and activities in themselves [9]

Regarding this research. Female prisoners should be able to form a better personality through their developmental process. Guidance and counseling services are not only done in schools but can also be done outside of schools such as in training institutions[10]. Although already in prison, it is possible that inmates will succeed in the future [11]. Therefore, guidance and counseling services are needed to improve the prisoners' self image so that they appear more confident about themselves, have high motivation to live, and can interact well with the community after being released later.

\section{LITERATURE REVIEW}

\section{Self Image}

Self Image can be influenced by the environment, experience, and from the individual itself. In a psychological dictionary, self image or self-image is the identity as described or imagined [12]. Self-image is what a person sees when he sees himself, which is often associated with physical characteristics, including one's general appearance, body size, how to dress, hairstyles and cosmetics use [13]. Therefore, it is said that selfimage consists of concepts owned by individuals against their choices [9].

Self-image is seen as a structure of layers of self and objects that are connected by feelings [14]. Self 
image has the function of controlling affective and cognitive experiences [15]. Self-image is considered to have a major influence upon individual behavior that can be used to understand and explain the behavior of various types [16]. Every individual is required to be able to build a positive self-image of [10]. So, Self-Image is the view or image that an individual has about himself and how he shows himself to others. Self-image is formed from birth both from the environment, experiences, failures, awards, reactions from others, as well as from the individual himself and unconsciously.

\section{Aspects of self-image}

Aspects of self-image (1) perceptual component, this component is an assessment that is owned by someone regarding their appearance or everything that includes a person's physical state; (2) conceptual component. Conceptual component is a person's conception of his characteristics, such as abilities or strengths, as well as his weaknesses or limitations; and (3) attitudinal component, matters relating to the social situation or environment of an individual regarding the individual's view of the judgment of others [17].

\section{Factor that influences the self-image}

Factors that determine the self-image of an individual includes behavioral factors, including: (1) selective behavior (selective attention) to input that supports an individual's self-image. Individuals tend to sort out, which input to consider; (2) paralyzing oneself. The individual gives rise to certain behaviors, which reduce his shortcomings; (3) the selection of tasks that show positive effort. Individuals are more likely to see input is indicative of their strengths, rather than their true abilities (unfavorable abilities); (4) evidence that clarifies information seeking behavior strategic. Individuals tend to avoid situations where deficiencies can be seen and individuals tend to seek input for things that are easily corrected from the results of their abilities [18].

Furthermore, social factors include (1) selective interaction. The individual can choose with whom he wants to get along; (2) Ordinary social comparisons. Individuals tend to compare themselves with others who think they are inferior to themselves.

\section{ROLE OF COUNSELOR AGAINST SELF- IMAGE FEMALE PRISONERS}

Guidance and Counseling are not only used for school, but Guidance and Counseling are also used outside the school, one of them is in Penitentiary Institutions. Guidance and Counseling service interventions are urgently needed to deal with psychological problems experienced by female prisoners both experienced while in prison and when they are released later or after being released from prison. In reality, female prisoners in prison have a lot of psychological problems, causing the self-image of female prisoners to decline. Female convicts lose their identity and personality, lose their self-control, have difficulty adjusting, have low self-esteem, has difficulty accepting the present situation, see themselves as a criminal, have less self-confidence and a high sense of despair. Besides that, female convicts get a bad image from society, the image of women who should be feminine will be linked to violence and crime so that female prisoners are considered as social trash, ostracized from the environment, rejected by society and must be watched out.

Based on these problems, counselors can help improve the self-image of female prisoners by providing various counseling and guidance services. According to [19] guidance and counseling are a process of assistance provided by counselors to individuals (counselees) through in person meetings or reciprocal relationships between the two, so that counselees can recognize their abilities and problems faced and have the ability to solve their own problems. Services that can be provided are:

\section{Orientation Service}

Orientation service is a guidance service that is carried out to introduce someone to the environment they at this moment entered [20], [21]. In this service, the counselor can help prisoners who have just entered detention and who will be released from detention by providing material about adjustment. This can help women prisoners go through the process of adjusting themselves in detention or adjusting themselves back to their long-lived environment.

\section{Information Service}

In general, information services are provided in conjunction with orientation services with the aim to provide understanding to individuals related to various things needed to carry out a task or activity, or to determine the direction, purpose, or something that is desired [20], [22]. Individuals are unique. Prisoners and women in prison certainly have unusual problems and different needs. In this service, the counselor provides information relating to the problems and needs of each prisoner such as information on how to increase motivation, how to increase self-confidence, stages in instilling religious values in female prisoners.

\section{Individual Counseling Services}

Individual counseling is intended as a special service in the in person relationship between counselor and counselee, in that relationship the counselee's problems are examined, and efforts are made to work with the client's own strengths [20], [23]. In this service, the counselor will talk face to face with female prisoners and talk about issues that are being felt by female prisoners and in this service, prisoners will be helped to be able to recognize themselves and be able to handle problems and alleviate problems experienced.

\section{Counseling Group}

Group counseling services are basically individual counseling services carried out in a group atmosphere, there are counselors, counselees (group members) of at least two people, there occurs counseling relationships such as individual counseling where there is also a disclosure of problems, tracing the cause, effect, problemsolving and evaluation and follow-up[20], [22]. In this 
service, prisoners will form groups and sit in a circle, here the counselor as a group leader will lead the flow of activities. During the inmate, activities will be trained in increasing the attitude of sympathy and empathy as well as helping improve the prisoners' thinking and understanding. The most important thing in this service is to discuss the problems experienced, the causes of the problems, solutions to problems, and evaluation and follow-up activities.

\section{Placement and Distribution Services}

Placement and distribution services are special services from various maintenance functions. The counselee will maintain the conditions. Maintenance of these conditions aims to enable the development process that is fast and smooth so that optimal conditions are achieved according to the stages of development being undertaken by individuals [20]. In prisons, there are many forums and activities to develop abilities, talents and interests, and hobbies. In this service, prisoners can channel their abilities, talents, and interests so that the development process runs smoothly and optimally.

\section{CONCLUSION}

Self-image is an individual's self-image of his choices as an individual regarding the appearance and feelings that accompany it, this picture is formed since childhood based on oneself, experience, environment, and views of others. In fact, according to the description above female prisoners have a negative self-image. Female prisoners lose their identity and personality, lose their self-control, have difficulty adjusting, have low selfesteem, find it difficult to accept the present situation, see themselves as a villain, have less self-confidence and a high sense of despair. In addition, female prisoners get a bad image from the community, so that female prisoners are considered as community trash, excluded from the environment, rejected by the community and considered as someone to watch out for. Thus, counselors have an important role in helping to improve the self-image of female prisoners by providing various types of guidance and counseling services such as orientation services, information services, individual counseling services, group counseling, and placement and distribution services.

\section{REFERENCES}

[1] Y. Sumarauw, "Narapidana Perempuan dalam Penjara (suatu Kajian Antropologi Gender)," J. Holistik, vol. 6, no. $11 \mathrm{~b}, 2013$.

[2] K. Kartono, "Patologi sosial jilid 1," Jakarta PT Rajagrafindo Persada, 2011.

[3] D. A. Kusumawardani and T. P. Astuti, "Perbedaan Kecemasan Menjelang Bebas Pada Narapidana Ditinjau
Dari Jenis Kelamin, Tindak Pidana, Lama Pidana, Dan Sisa Masa Pidana," Empati, vol. 3, no. 3, pp. 52-60, 2014.

[4] [D. I. Utari, N. Fitria, and I. Rafiyah, "Gambaran tingkat kecemasan pada warga binaan wanita menjelang bebas di Lembaga Pemasyarakatan wanita kelas II A Bandung," Student e-journals, vol. 1, no. 1, pp. 1-15, 2012.

[5] D. D. Cooke, P. J. Baldwin, and J. Howison, Menyingkap dunia gelap penjara. Gramedia Pustaka Utama, 2008.

[6] N. Wisma, H. Nirwana, and Afdal, "Differences in emotional regulation of Bugis student and Malay cultural background Implications for counseling and guidance services," Int. J. Res. Couns. Educ., vol. 2, no. 1, pp. 32 39, 2018.

[7] A. Y. Periwi, Hubungan antara Fukungan Orang Tua denganKonsep Diri pada Narapidana di Lembaga Pemasyarakatan Klas II A Bukittinggi. Padang: UNP, 2019.

[8] D. P. Hilman and E. S. Indrawati, "Pengalaman Menjadi Narapidana Remaja di Lapas Klas I Semarang," Empati, vol. 6, no. 3, pp. 189-203, 2018.

[9] M. Maltz, The Magic Power of Self Image Psychology. Bombay: Jaico Publishing House, 1994.

[10] T. N. Ramadhani and F. G. Putrianti, "Hubungan antara Kepercayaan Diri dengan Citra Diri pada Remaja Akhir," J. Spirits, vol. 4, no. 2, pp. 22-32, 2014.

[11] A. Alizamar, A., Fikri, M., \& Afdal, "The Exploration of Young Prisoners Social Anxiety. Proceedings of the International Conferences on Educational, Social Sciences and Technology - ICESST 2018. doi:10.29210/2018118," in Proceedings of the International Conferences on Educational, Social Sciences and Technology - ICESST 2018. doi:10.29210/2018118, 2018.

[12] M. Veronika and A. Afdal, "Differences in Self-Concept of Students from Intact Families And Non-Intact Families," JAIPTEKIN | J. Apl. IPTEK Indones., vol. 3, no. 3, pp. 151-158, 2019.

[13] Burns R. B., Konsep Diri: Teori, Pengukuran, Perkembangan dan Prilaku. Jakarta: Arcan, 1993.

[14] D. N. Stern, interpersonal world of the infant. New York: Basic Books, 1985.

[15] M. J. Horowitz, Person schemas. In M.J. Horowitz (Ed.), Person schemas and maladaptive interpersonal patterns. Chicago: University of Chicago Press, 1991.

[16] G. C. Shavelson, R. J., Hubner, J. J. \& Stanton, "Selfconcept: Validation of construct interpretations," Rev. Educ. Res., vol. 46, pp. 407-441, 1976.

[17] A. T. Jersild, The Psychology of Adolescent. New York: The Mc Millan, 1963.

[18] J. . Brown, The Self. Boston: Mc Graw-Hill, 1998.

[19] Tohirin, Bimbingan dan Konseling di Sekolah dan Madrasah. Jakarta: Rajawali Pers, 2013.

[20] Prayitno \& Erman Amti, Dasar-dasar Bimbingan dan Konseling. Jakarta: Rineka Cipta, 2015.

[21] Prayitno, Konseling Profesional yang Berhasil: Layanan dan Kegiatan Pendukung. Jakarta: Rajawali Pers, 2017.

[22] Prayitno, Jenis Layanan dan Kegiatan Pendukung Konseling. Padang: FIP UNP, 2012.

[23] Prayitno, Wawasan Profesional Bimbingan dan Konseling. Padang: Universitas Negeri Padang., 2016. 